\title{
SERVIDOR ESTADUAL - TETO DE VENCIMENTOS - PARADIGMA
}

Ação direta de inconstitucionalidade. 2. Art. $2^{2}$ da Lei Complementar $n^{0}$ 16, de 08/11/1996, do Estado de Pernambuco. Regime Jurídico dos servidores públicos civis do Estado. Teto de vencimentos do funcionalismo estadual correspondente ao valor da remuneração atribuida, em espécie, ao Governador do Estado. 3. Alegação de ofensa aos arts. 37, XI e 39, § 10, da Constituição Federal. 4. A Corte firmou entendimento na ADIN 1674-5-DF, no sentido de que o teto de vencimentos, em cada Poder, deve se referir aos percebidos pelos Deputados Estaduais, Secretários de Estado e Desembargadores do Tribunal de Justiça, excluindo-se desse teto as vantagens de caráter pessoal percebidas pelos servidores, a teor dos artigos 37, XIII e 39, $\S 1^{\prime \prime}$, da CF de 1988. 5. Relevantes os fundamentos da inicial e conveniente a suspensão cautelar da vigência do dispositivo impugnado. 6. Medida cautelar deferida para suspender, "ex nunc" $e$ até o julgamento final da ação a eficácia do art. $2^{-}$da Lei Complementar no 16/1996, do Estado de Pernambuco. 
SUPREMO TRIBUNAL FEDERAL

Ação Direta de Inconstitucionalidade $n^{2} 1.833$

Requerente: Procurador Geral da República

Requerido: Governador do Estado de Pernambuco

Relator: Sr. Ministro NÉRI DA SILVEIRA

\section{ACÓRDĀO}

Vistos, relatados e discutidos estes autos acordam os Ministros do Supremo Tribunal Federal em sessão Plenária, na conformidade da ata de Julgamentos e das notas taquigráficas, por votação unânime, deferir o pedido de medida cautelar, para suspender, até final julgamento da ação direta, com eficácia ex nunc, a execução e aplicabilidade do art. $2^{2}$ da Lei Complementar $n^{2} 16$, de 08/01/1996, do Estado de Pernambuco.

Brasília, 27 de maio de 1998.

MINISTRO CELSO DE MELLO - PRESIDENTE

MINISTRO NÉRI DA SILVEIRA - RELATOR

\section{RELATÓRIO}

O SENHOR MINISTRO NÉRI DA SILVEIRA (RELATOR):

O Dr. Procurador-Geral da República aforou ação direta de inconstitucionalidade do art. 22, da Lei Complementar $n^{2} 16 / 1996$, do Estado de Pernambuco, que dispõe sobre o regime jurídico dos servidores públicos civis do Estado, verbis:

"Art. $2^{2}$ - Em nenhuma hipótese, a remuneração, os proventos da aposentadoria dos servidores públicos e as pensões poderão superar o valor da remuneração atribuída, em espécie, ao Governador do Estado, nāo se admitindo excesso de qualquer natureza ou a percepção de qualquer parcela decorrente de vantagens pessoais."

Alega-se que a inconstitucionalidade do dispositivo reside na ofensa ao art. 37, XI, da Lei Maior, ao estabelecer como teto dos ven- cimentos do funcionalismo estadual os valores percebidos em espécie, pelo Governador do Estado, quando, "segundo a disciplina constitucional, os limites máximos dos vencimentos devem ter por referência, no âmbito dos respectivos poderes, o valor percebido, em espécie e a qualquer título, pelos Secretários de Estado, Deputados Estaduais e Desembargadores do Tribunal de Justiça. Acrescenta-se que o dispositivo em foco está em desconformidade também com o art. $39, \S 12$, da Constituição, "ao desconsiderar do teto de vencimentos as parcelas correspondentes a vantagens pessoais, que se acham excluídas da limitação pelo disposto no art. $39, \S 12$, da Constituiçãa”.

A inicial refere, também, precedente do STF, na ADIN - 'Medida Cautelar' - $\mathbf{n}^{\mathrm{e}}$ 1.674-5-DF.

Pleiteia-se, na inicial, cautelar para suspender a eficácia da norma impugnada, até o julgamento final da presente ação.

Em face da súplica de liminar, submeto ao Plenário o feito.

É o relatório.

\section{VOTO}

O SENHOR MINISTRO NÉRI DA SILVEIRA (RELATOR):

Na ADIN - Medida Cautelar - $\mathrm{n}^{2} 1.674-$ 5-DF, a respeito de matéria semelhante, a Corte deferiu a laminar, estando o acórdão respectivo assim ementado (fls. 3/4):

"DIREITO CONSTITUCIONAL. TETO DE VENCIMENTOS E PROVENTOS (ART. 37, XI, DA CONSTITUIÇÃO FEDERAL DE 1988). VANTAGENS PESSOAIS (ART. 39, § 19). AÇÃO DIRETA DE IN- 
CONSTITLICIONALIDADE DA EMENDA CONSTITUCIONAL NN20, DE 10.09.1997, DO ESTADO DE GOIÁS. MEDIDA CAUTELAR.

1. A Emenda Constitucional $n^{\circ} 20$, de 10.09.1997, do Estado de Goiás, acrescentou o $\S 8^{\circ}$ do art. 92 da Constituição Estadual, nestes termos:

'§ 6o - É vedado aos Chefes e demais membros dos Poderes Executivo, Legislativo e Judiciário, aos agentes políticos, aos funcionários, servidores e empregados públicos, civis e militares, ativos e inativos, inclusive, no âmbito da administração estadual, direta e indireta, perceber, mensalmente, remuneraçāo, provento ou pensão, a qualquer título, em quantia superior à percebida pelo Governador do Estado.

I - Excluem-se do limite estabelecido neste parágrafo o décimo terceiro salário, a remuneração de férias e a retribuição devida em razāo de acumulaçāo legítima de cargos ou funções públicas e mandatos eletivos.

II - Toda remuneração que estiver sendo percebida além do limite estipulado neste artigo será reduzida ao valor ali estipulado'.

2. A Emenda Constitucional estadual, em questão, a um primeiro exame, para o efeito de Medida Cautelar, parece violar o disposto na Constituição Federal, pois estabelece, como teto de vencimentos, os do Governador do Estado, quando deveria se referir aos percebidos pelo Deputados Estaduais, pelos Secretários de Estado e pelos Desembargadores do Tribunal de Justiça. E ainda considera abrangidas por esse teto as vantagens pessoais percebidas pelos servidores públicos, quando estas dele se acham excluídas, nos termos dos artigos 37 , XIII, e 39, $§ 1^{\text {I }}$, da CF de 1988 , segundo jurisprudência firmada pelo STF, seja em Ações Diretas de Inconstitucionalidade, seja em Recursos Extraordinários.

3. Satisfeito o requisito da plausibilidade jurídica da ação ("fumus boni iuris"), assim como o do "periculum in mora". defere-se a Medida Cautelar para suspensão, "ex-nunc”, da efícácia da E.C. n² 20/97, do Estado de Goiás, até o julgamento final da ação.
4. Plenário. Decisão unânime, quanto à concessão da medida. e. por maioria, quanto a sua eficácia." (DJ 28.11.97, pág. 62217)."

Efetivamente, do inciso XI do art. $37 \mathrm{da}$ Constituição, no âmbito dos Estados-membros, consideram-se situaçōes referenciais do teto os valores percebidos como remuneração, em espécie. a qualquer título, pelos Deputados estaduais, os Secretários de Estado e Desembargadores do Tribunal de Justiça. Não cabe, assim. à lei local, substituir o que consta de norma maior federal expressamente quanto aos Estados e Distrito Federal, como preceito de obrigatória observância.

Também, da conjugação dos arts. 37. XI, e $39, \S 1^{2}$, ambos da Constituição Federal, esta Corte tem afirmado, desde o julgamento da ADIN $n^{2} 14$, que as vantagens pessoais não se compreendam nos limites do teto previsto no XI do art. 37 da Carta Política. Nesse sentido, dentre outros, ADIN 1344, Rel. Min. Moreira Alves; AgRgAg 154.555, rel. Min. Sepúlveda Pertence; RE 160.860, de que fui relator; RE 164.573, rel. Min. Marco Aurélio; RE 141.788, rel. Min. Sepúlveda Pertence; RE 161.263, rel. Min. Maurício Corrêa.

$\mathrm{Na}$ linha do precedente referido, defiro a cautelar e suspendo, ex nunc e até o julgamento final desta ação, a eficácia do art. $2^{\mathfrak{Q}} \mathrm{da}$ Lei Complementar n 167/1996, do Estado de Pernambuco.

\section{EXTRATO DE ATA}

AÇÃO DIRETA DE INCONSTITUCIONALIDADE № 1.833-6 - medida liminar

PROCED.: PERNAMBUCO

RELATOR: MIN. NÉRI DA SILVEIRA

REQTE.: PROCURADOR-GERAL DA REPÚBLICA

REQDO:: GOVERNADOR DO ESTADO DE PERNAMBUCO

REQDA.: ASSEMBLÉIA LEGISLATIVA DO ESTADO DE PERNAMBUCO

Decisão: $\mathrm{O}$ Tribunal, por votação unânime, deferiu o pedido de medida cautelar, para suspender, até final julgamento da ação direta, com eficácia ex nunc, a execução e aplicabi- 
lidade do art. $2^{2}$ da Lei Complementar $n^{2} 16$, te, neste julgamento. o Ministro Ilmar Galvăo. de 08/01/1996, do Estado de Pernambuco. Plenário, 27.5.98.

Votou o Presidente. Ausente, justificadamen- Luiz Tomimatsu, Coordenador 